https://doi.org/10.30910/turkjans.680081

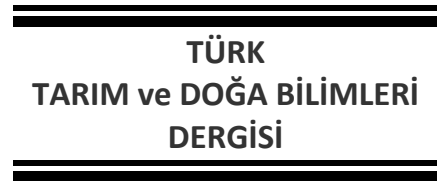

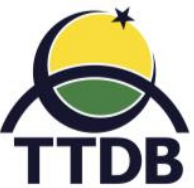

www.dergipark.gov.tr/turkjans

Araştırma Makalesi

\title{
İç Anadolu Bölgesinde Faaliyette Bulunan Gıda Toptancıları Çalışanlarının Yöneticilerine Güven Düzeyleri: Cips Toptancıları Örneği
}

\author{
Halil Özcan ÖZDEMiR ${ }^{1 *}$, Ufuk KARADAVUT² ${ }^{2}$, Galip ŞiMŞEK ${ }^{2}$ \\ ${ }^{1}$ Kırşehir Ahi Evran Üniversitesi, Ziraat Fakültesi, Tarım Ekonomisi Bölümü Kırşehir \\ ${ }^{2}$ Kırşehir Ahi Evran Üniversitesi, Ziraat Fakültesi, Zootekni Bölümü Kırşehir \\ *Sorumlu yazar: hoozdemir@ahievran.edu.tr
}

Geliş Tarihi: 17.10.2019

Düzeltme Geliş Tarihi: 08.01.2020

Kabul Tarihi: 08.01.2020

\section{Özet}

Bu çalışmanın amacı, İç Anadolu Bölgesinde faaliyette bulunan özellikle cips grubu gıda ürünlerin dağıtımı ile ilgilenen firmalardaki çalışanların yöneticilerine duydukları güven düzeylerini belirlemektir. Bu kapsamda toplam 210 çalışana anket uygulanarak veriler elde edilmiştir. Araştırma sonucunda; çalışanların işverenleri hakkında belli bir seviyede güven duymakla birlikte kafaların netleşmediği ve bir miktarda karışıklığın olduğu görülmektedir. Çalışanların \%97 sini erkek çalışanlar oluşturmaktadır. Çalışanların \%43’lük kısmı 20-29 yaş aralığındaki çalışanlardan oluşmaktadır. Çalışanların \%57 gibi büyük çoğunluğu orta öğretim mezunlarından oluşmaktadır. Maaş düzeyleri incelendiğinde çalışanların genellikle asgari ücret seviyesinde maaş aldıkları görülmektedir. Çalışanların kıdemleri incelendiğinde \%40'ık kısmı 6-10 yıl arası çalışanlardan oluşmaktadır. Yapılan korelasyon analizine göre yaş ilerledikçe idarecileri tanıma daha da arttığı için güven duygusu ve bilgileri paylaşma oranları da artmaktadır.

Anahtar kelimeler: Yöneticiye güven, gıda toptancıları, örgütsel davranış, işgören.

\section{Confidence Levels of Food Wholesaler Employees Operating in Central Anatolia Region to Their Managers: Chips Wholesalers Sample}

\begin{abstract}
The aim of this study was to determine the trust level of the employees to their managers in the companies dealing with the general distribution of the chips group in the region of Central Anatolia. In this scope, the data were obtained by using a questionnaire forms with 210 employees. As a result of the research; although there was a certain level of confidence to their managers, but it wasn't completely clear and there was some confusion. $97 \%$ of the employees was male. $43 \%$ of the employees was between $20-29$ years of age. $57 \%$ of the employees were secondary school graduates. When the salary levels are examined, it is seen that the employees generally receive salaries at the minimum wage level. When the tenure of the employees is examined, $40 \%$ of the employees are between 6-10 years. According to the correlation analysis, as the age increases, the sense of trust and sharing of the information increases as the recognition of the administrators increases.
\end{abstract}

Key words: Trust to managers, food wholesalers, organizational behavior, employee.

Giriş

Pazarlama alıcı ile satıcıyı bir araya getiren sistemin genel adıdır. Bunun için yer ve zamanın da buna uygun bir şekilde ayarlanmış olması gerekmektedir. Pazarlama çalışmaları oldukça geniş bir süreyi ve süreci kapsamaktadır. Pazarlama faaliyeti üretilen ürüne karar vermekten başlayıp son tüketiciye ulaşması ve satış sonrası faaliyetleri de kapsayan uzun bir süreçtir. Çünkü alınan ürünün genel olarak belli standartlarda olması ve bu standartlar kapsamında satıştan önce olduğu gibi satış sonrasında da bazı sorumlulukların satıcıya 
yüklenmesine sebep olmaktadır. Ne tür ürün alınırsa alınsın, bu sorumluluk artık satıcıların sorumluluğu altındadır.

Tarım ürünleri yapı itibariyle diğer ürünlerden çok farklı yapıya sahiptirler. Bunun temel nedeni yapı olarak biraz daha hassas olmaları ve depolama bakımından uzun süre muhafaza edilememeleridir. Muhafaza koşullarının iyi olmaması da ayrıca ürünün ömrünü kısaltan büyük bir sorun olarak karşımızda durmaktadır. Gıda maddeleri son tüketiciye kadar giderken özel ilgi beklemektedir (Albayrak, 2009). Çünkü alınan ürün bir giyisi ise bunu iade edebilirsiniz. Elektronik bir eşya ise bunu yine geri verebilir ya da servisine gönderebilirsiniz. Ancak gıda maddesinde böyle bir şansınız yoktur. Özellikle bunun eski veya bozuk olduğu konusunda bilginiz yoksa sağlığınız ciddi tehlike altına girebilir. Yediğiniz ya da içtiğiniz gıda maddesi sizleri zehirleyebilir ve hatta öldürebilir.

Üretilen gıda ürününün sahip olduğu yapısal farklılık ürünün üretiminden son tüketiciye ulaştırılmasına kadar geçen sürenin ve yapılacak işlemlerin belirlenmesinde kilit rol oynamaktadır. Pazarlaması yapılan ürün et ve süt ürünlerinden veya çok çabuk bozulabilen sebze ve meyvelerden oluşuyorsa bunların pazarlama koşullarına diğer ürünlere göre daha fazla özen gösterilir. Türkiye'de pazarlama kanalları olarak üretici, toptancı ve tüketici bağlarının korunması gerekir (Yurdakul ve Koç, 1997). Burada toptancılar üretici ile tüketici arasındaki bağlantıyı sağlamaktadırlar (Erbay, 2007). Eğer satılan ürünler paketli ürünler ise toptancılar için daha rahat olmaktadır. Çünkü bu tip ürünlerin satışı, pazarlaması ve muhafazası daha rahat olmaktadır.

Dünya genelinde cips pazarı 2005 yılından itibaren büyüme eğilimine girmiştir. 2005 yılında 16.5 milyar dolar düzeyinde iken, günümüzde 46.1 milyar dolara çıkmıştır (Karahan, 2019). Cips Türkiye'de tüketimi yapılan önemli gıda maddelerinden birisidir. 2000'li yıllardan itibaren hızla hayatımıza giren bu maddelerin kullanımı hızla artmaktadır. Türkiye'de 2002 yılında 233 milyon dolarlık bir pazar varken, günümüzde 2 milyar dolarlık bir pazar oluşmuştur (TÜRKTOB, 2018). Ayrıca kişi başı cips tüketimi 2002 yılında 400 gram iken, günümüzde bu rakam bir kilogramı geçmiş durumadır. Özellikle genetiği değiştirilmiş organizmaların (GDO) tüketiminden kaynaklı olumsuzluklar için duyulan kaygı miktarının artışı bu ürünlerin tüketimde bir miktar durgunluğa sebep olsa da kısa süreli olmuş ve artış devam etmiştir (Mutlu, 2016). Cips pazarı özellikle pazarlama stratejilerinin gelişmesi ve satıcıların gençlerin zayıf noktalarına yönelik olarak ciddi vuruşlar yapmaları nedeniyle sürekli olarak artış göstermektedir. Yapılan bu çalışma ile İç Anadolu bölgesinde cips alanında toptan satış yapan iletmelerdeki çalışanların durumları incelenmek istenmiştir.

Yönetim, başkalarına iş yaptırma, başkaları üzerinde otorite kurma veya bir grup içindeki kişileri ortak bir amaç doğrultusunda istenilen sonuçları elde edebilecek biçimde yönlendirme süreci olarak değerlendirilir (Eryılmaz, 2011). Yöneticiyi işgörenlerin gözünde güvenilir yapan, onun kişisel bütünlüğü ve yönetsel etkililiğidir. Yetkinlik, tutarlılık, dürüstlük, yardımseverlik, ilgi gösterme özellikleri, yöneticinin çalışanın gözünde güvenilirliğini arttırarak kendi çıkarını düşünmediğini gösterir. (Eren ve Hayatoğlu, 2012). $\mathrm{Bu}$ gibi davranışların neticesi olarak yöneticisine güvenen işgören organizasyonu için daha faydalı hale gelebilecek ve örgütün amaçlarına ulaşmasında katkısı artmış olacaktır.

Yöneticiye duyulan güven ile ilgili yapılmış çalışmalara bakıldığında; örgütsel davranış konularından birisi ile yöneticiye duyulan güven arasındaki ilişkilere yönelik yapılmış çalışmaların çokluğu dikkati çekmektedir. Aslan ve Özata (2009) yaptıkları çalışmada lider-üye değişiminin (Imx) yöneticiye duyulan güven üzerindeki etkisine bakmışlar lider-üye etkileşimini olumlu değerlendirenlerin örgütsel güven düzeylerinin de yüksek olduğu sonucunu elde etmişlerdir. Yolaç (2011) yapmış olduğu çalışmada algılanan liderlik tarzları ile yöneticiye duyulan güven arasındaki ilişkide lider-üye etkileşiminin rolünü incelemiş ve çalışma sonucunda dönüşümcü liderlik tarzının yöneticiye duyulan güveni açıklamada önemli etkisinin olduğunu tespit etmiştir. Arslantaş (2008) yapmış olduğu çalışmada yöneticiye duyulan güven ile psikolojik güçlendirmenin örgütsel vatandaşlık üzerindeki etkilerini incelemiştir. Araştırma sonucunda; yöneticiye duyulan güvenin örgütsel vatandaşlığın çalışanlar arasındaki uyum boyutu üzerinde bir etkiye sahip olduğunu tespit etmiştir.

Connell, Ferres ve Travaglione (2003) yaptıkları çalışmada, yöneticiye duyulan güvenin sonuçları ile ilgili Avusturalya da yaptıkları çalışma sonucunda; algılanan örgütsel desteğin rutin adaletin ve dönüşümsel liderliğin, yöneticilere duyulan güvenin önemli belirleyicileri olduğunu belirlemişlerdir.

\section{Materyal ve Yöntem}

Genel olarak araştırmacılar perakende satıcılar üzerinde çalışmalar yapmaktadırlar. Oysa üretilen malların perakendecilere gidene kadar ki en önemli durakları toptancılardır. Gıda toptancıları pazarlama karmasındaki dağıtım fonksiyonu için önemli bir görevi yürütmektedirler. Çalışma yapılan alanda 20 ana dağıtım noktası ve 100 civarında tali dağıtım noktası bulunmaktadır. 
Gayeli örnekleme yöntemi kullanılarak buralarda çalışanların tamamına ulaşılmaya çalışılmıştır. Buna göre İç Anadolu Bölgesinde faaliyette bulunan cips dağıtım işletmelerinde çalışan ve ulaşılabilen 210 kişi ile birebir görüşmeler yapılmıştır. Çalışmalarda sorulan sorularda önce bireyleri tanımaya yönelik demografik sorular sorulmuş ve sonrasında ise yöneticiye duyulan güvenlerini ölçmek için literatürde kabul görmüş ve birçok araştırmacı tarafından kullanılmakta olan McAllister (1995)'in Yöneticiye Duyulan Güven Ölçeği kullanılmıştır. Elde edilen veriler dikkatli bir şekilde düzenlenmiştir. Katılımcılara ait frekansları, oransal durumları, ortalamaları ve standart sapma değerleri belirlenmiştir. Daha sonra ise elde edilen verilerin nitel veri olması nedeniyle nitel verilerin analizlerinde yoğun bir şekilde kullanılan Ki kare analizi yapılarak farklıklar tespit edilmiştir. Elde edilen verilerin parametrik olmamasından dolayı incelenen değişkenler bakımından aralarında ilişkin olup olmadığını belirleyebilmek için Spearman Korelasyon katsayıları hesaplanmıştır. Çalışmada yapılan analizler SPSS 21 istatistik paket programı kullanılarak yapılmıştır.

\section{Bulgular ve Tartışma}

Yapılan çalışmada katılımcıların cinsiyetlerine göre dağılımı Şekil 1'de verilmiştir. Şekil incelendiğinde çalışanların genel olarak erkeklerden oluştuğu görülmektedir. Bütün çalışanlar içinde erkeklerin oranı \%97 gibi oldukça büyük bir oranı oluştururken, kadınların oranı ise sadece \%3'te kalmıştır. Elde edilen bu sonucun genel olarak beklenen bir sonuç olduğunu söyleyebiliriz. Çünkü özellikle toptan satış yapılan alanlardaki çalışma koşullarının bayanlar için çok ta uygun olmaması ve işin ağırlığı dikkate alındığında bayanların bu mesleği tercih etmek istememelerinden çok işverenlerin bayan tercih etmek istememeleri ön plana çıkmaktadır. Özellikle yük indirme ve yükleme aşamalarında erkek yoğun işin olması işvereni bu yöne yönlendirdiği düşünülmektedir. Yapılan ikili görüşmelerde de bu yönde görüşler belirtilmiştir.

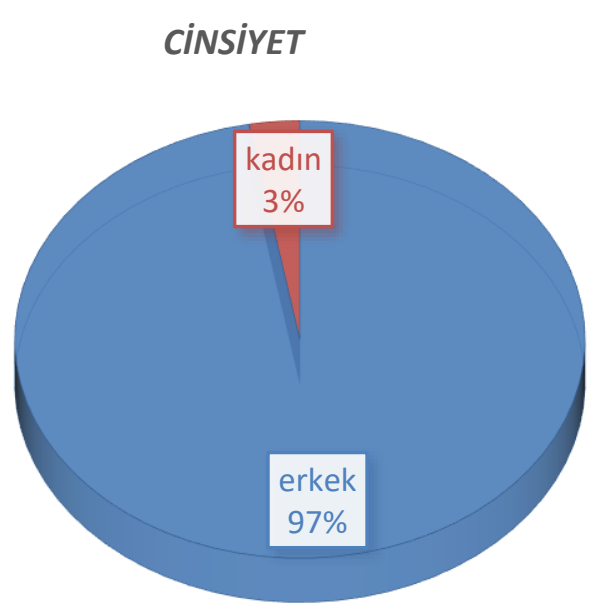

Şekil 1. Çalışanların cinsiyete göre dağılımı

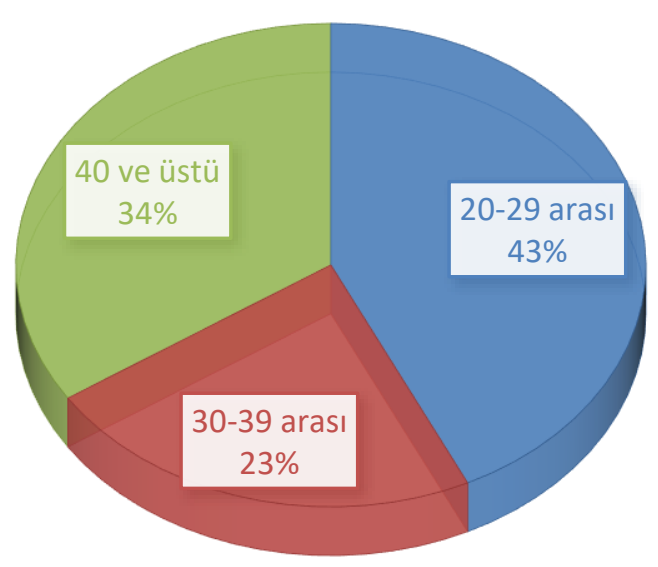

Şekil 2. Çalışanların yaşa göre dağılımı 
Çalışanların yaş durumlarının dağılımı Şekil 2'de gösterilmektedir. Çalışanların \%43'lük kısmı 20-29 yaş aralığında yer almaktadır. \%34'ü 40 ve üzerinde yaşa sahip olurken, \%23'ü 30-39 yaş aralığında yer almıştır. Aslında bakılırsa \%66'।ık kısım 20-39 yaş aralığında olan bireylerden oluşmaktadır. Bu yaş gruplarında yoğunlaşmasının temel nedeninin yapılan işin özelliğinden kaynaklanmaktadır.
Eğitim durumları bakımından yapılan incelemede elde edilen sonuçlar Şekil 3'te gösterilmiştir. Çalışanların $\% 57$ gibi büyük çoğunluğu orta öğretim mezunlarından oluşmaktadır. Bunu \%26 ile ön lisans mezunları izlemiştir. Lisans mezunu sayı \%6 ile en alt düzeyde kalmıştır. Buna göre bu meslekte çalışanların $\% 83^{\prime}$ lük kesimi lise ve ön lisans mezunlarından oluşmaktadır. Dört yıllık üniversite mezunlarının bu işi pek tercih etmedikleri anlaşılmaktadır.

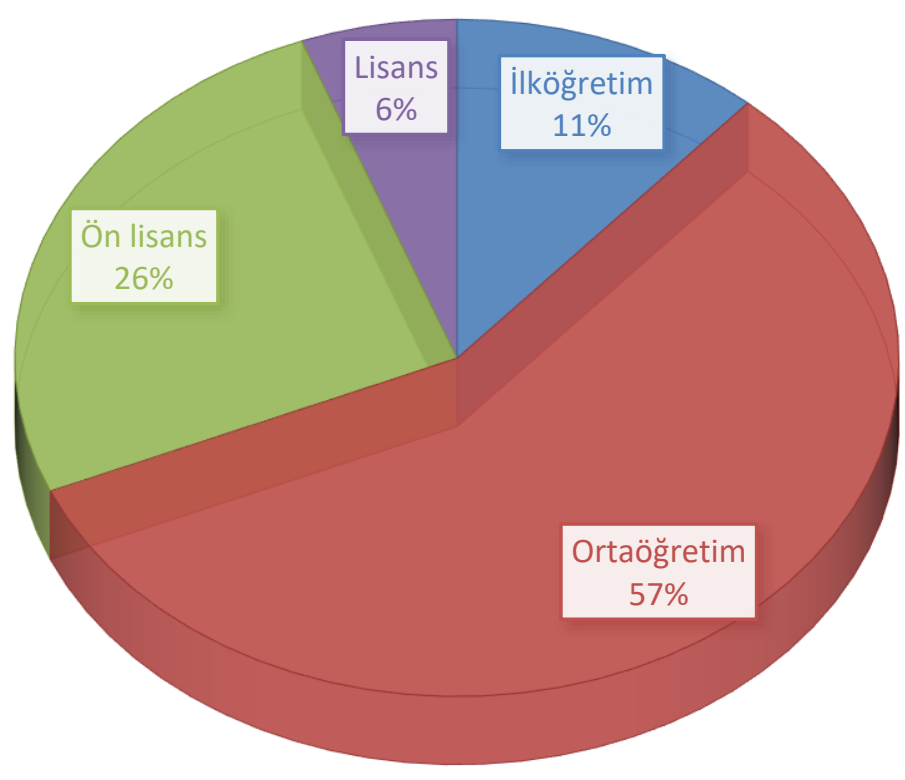

Şekil 3. Çalışanların eğitim durumlarına göre dağılımı

Gelir durumları bakımından yapılan incelemede genel olarak asgari ücret civarında maaş aldıkları görülmektedir. En yüksek oran 20012500 TL arasında alan kısım \%60 ile ilk sırada yer almıştır. Bunu \%28.6 ile 2501 ve üzerinde geliri olanlar izlemiştir. Ancak bu gelir grubuna sahip olanların genel olarak uzun süredir çalışanlar olduğunu belirtmek gerekir. Belli bir süreyi tamamlayan çalışanların işveren tarafından benimsendiği ve maaşlarının bir miktar artırıldığı gözlemlenmiştir. En düşük maaş alanlar ise $1500 \mathrm{TL}$ ve altında gelir elde etmektedirler ki bunların oranı ise sadece \%5.7 olarak tespit edilmiştir. Bu sonuçlara göre bu işi gelir seviyesi düşük olan kişilerin zorunlu tercih ettikleri görülmektedir.

Çalışanların toplam çalışma süreleri incelendiğinde elde edilen sonuçlar Şekil 4'de gösterilmektedir. Buna göre çalışanların yaklaşık yarısı (\%46) 16 yıl ve üzerinde bir çalışma süresine sahiptir. Tespit edilen bu süre deneyim kazanma ve hayata yön verme anlamında oldukça önemlidir. \%28'i 6-10 yıl arasında çalışırken, \%23'ü 11-15 yıl arasında çalışmaktadır. Buna göre çalışanların \%69'unun 11 yıl ve üzerinde bir deneyime sahip oldukları görülmektedir. Deneyimsiz olarak değerlendirilebilecek olan 1-5 yıllık çalışanların oranı ise \%3'te kalmıştır. Buna göre gıda toptancılığı yapan işletmelerin eleman tercihi yaparken en az 6 yıl ve üzerinde bir çalışma deneyimi istemektedirler 


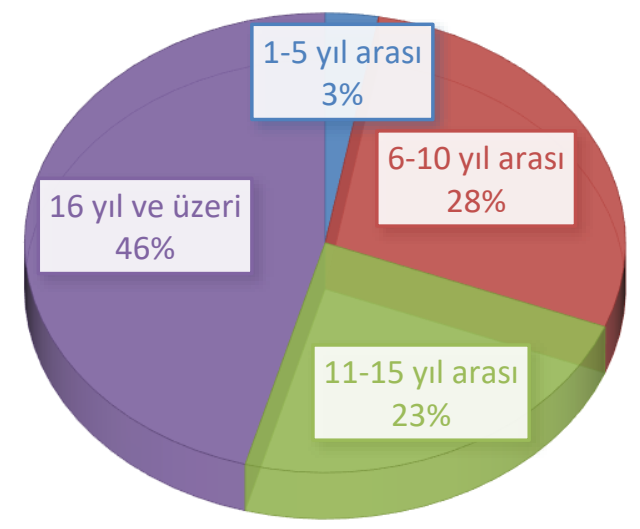

Şekil 4. Çalışanların toplam çalışma sürelerine göre dağılımı

Gıda toptancı olan iş yerlerinde çalışanların halen bulundukları yerde çalışma süreleri incelendiğinde ancak \%12'sinin halen bulunduğu yerde çalıştığı anlaşılmaktadır. 11-15 yıl arasında çalışanların ise \%17'lik bir kısmı oluşturmaktadır. En yüksek miktarı ise \%40 ile 6-10 yıl arasında çalışanlar oluşturmaktadır (Şekil 5). Çalışma süreleri her meslekte olduğu gibi bu meslek grubunda da ön plana çıkmaktadır. Özellikle çalışanların işlerinden memnun olması ve tutarlılık açısından önemlidir. Sürekli olarak iş ve iş yeri değiştiren bireylerin genel olarak tutunma şansları olmamaktadır. Bu işyerinin geleceği açısından alınacak kararları ciddi anlamda etkileyebilmektedir.

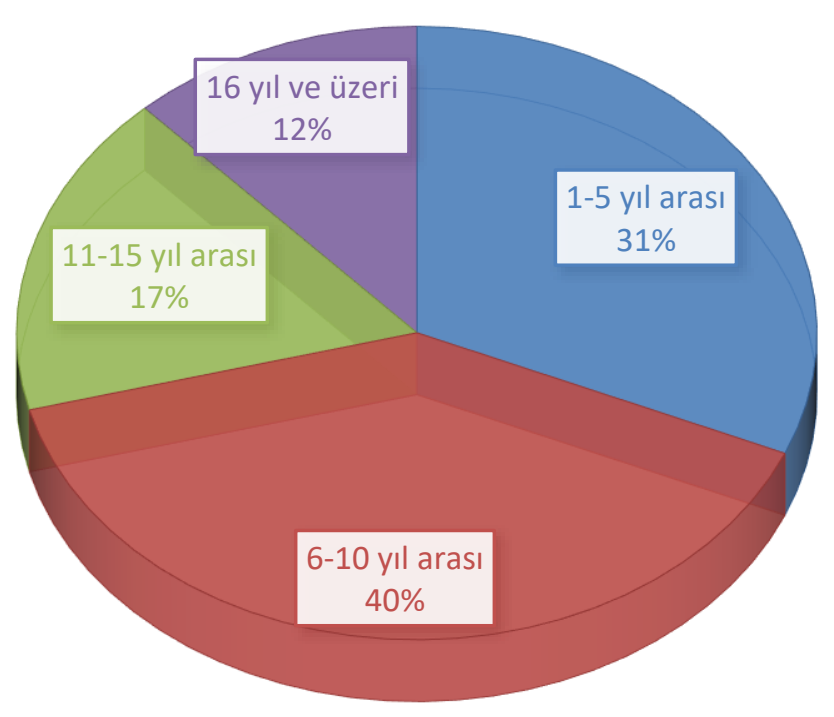

Şekil 5. Çalışanların çalıştıkları yerdeki çalışma sürelerine göre dağılım

Yapılan çalışmada elde edilen sonuçlar arasındaki farklılıkları belirleyebilmek için ki kare analiz yapılmıştır. Elde edilen sonuçlar Çizelge 1'de verilmektedir. Çizelge incelendiğinde cinsiyet açısından 186.686 ki kare değeri ile farklılığın 0.01 'e göre önemli olduğu görülmüştür. Yaş bakımından incelendiğinde ise bu değerin 12.686 olduğu ve ancak 0.05 'e göre önemli olduğu görülmüştür. Eğitim durumu bakımından da oldukça önemli farkların olduğu görülmektedir. Eğitim durumu bakımından yapılan analiz sonucunda Ki kare değerinin 133.543 değerine sahip olduğu ve 0.01 'e göre önemli olduğu gözlenmiştir. Özellikle orta öğretim mezunlarının sayılarının ciddi anlamda yüksek olması bu farklılığın oluşmasında etkili olduğunu düşündürmektedir. Gelir düzeyleri bakımından yapılan analiz sonucunda 166.457 değeri ile, şu anda bulundukları işyerinde çalışma süreleri göre 40.781 değeri ile ve toplam çalışma süreleri bakımından 78.267 değeri ile 0.01 'e göre önemlilik tespit edilmiştir. 
Çizelge 1. Çalışanların demografik özelliklerinin Ki kare analiz sonuçları

\begin{tabular}{|c|c|c|c|c|c|}
\hline Gruplar & Gözlenen(O) & Beklenen(E) & Gruplar & Gözlenen (O) & Beklenen(E) \\
\hline \multicolumn{3}{|c|}{$\begin{array}{l}\text { Katılımcıların Cinsiyet Değişkenine Göre } \\
\text { Ki-Kare }\left(X^{2}\right)\end{array}$} & \multicolumn{3}{|c|}{$\begin{array}{l}\text { Katılımcıların Şu Anda Bulundukları İşyerinde Çalışma } \\
\text { Süreleri Değişkenine Göre Ki-Kare }\left(X^{2}\right)\end{array}$} \\
\hline \multirow[t]{2}{*}{ Erkek } & 204 & 105.0 & 1-5 yıl arası & 66 & 52.5 \\
\hline & & & 6-10 yıl arası & 83 & 52.5 \\
\hline \multirow[t]{2}{*}{ Kadın } & 6 & 105.0 & $11-15$ yıl arası & 36 & 52.5 \\
\hline & & & 16 yıl ve üzeri & 25 & 52.5 \\
\hline Toplam & 210 & 210.0 & Toplam & 210 & 210.0 \\
\hline $\operatorname{Ki-Kare}\left(X^{2}\right)$ & & $86 * *$ & Ki-Kare $\left(X^{2}\right)$ & & $1 * *$ \\
\hline \multicolumn{3}{|c|}{$\begin{array}{l}\text { Katılımcıların Yaş Değişkenine Göre } \\
\text { Ki-Kare }\left(X^{2}\right)\end{array}$} & \multicolumn{3}{|c|}{$\begin{array}{l}\text { Katılımcıların Toplam Çalışma Süreleri Değişkenine } \\
\text { Göre Ki-Kare }\left(X^{2}\right)\end{array}$} \\
\hline 20 yaş ve altı & - & - & 1-5 yıl arası & 6 & 52.5 \\
\hline $20-29$ arası & 90 & 70.0 & $6-10$ yıl arası & 59 & 52.5 \\
\hline 30-39 arası & 48 & 70.0 & $11-15$ yıl arası & 49 & 52.5 \\
\hline 40 ve üstü & 72 & 70.0 & 16 yıl ve üzeri & 96 & 52.5 \\
\hline Toplam & 210 & 210.0 & Toplam & 210 & 210.0 \\
\hline $\operatorname{Ki-Kare}\left(X^{2}\right)$ & & $86 *$ & $\operatorname{Ki-Kare}\left(X^{2}\right)$ & & $7 * *$ \\
\hline \multicolumn{3}{|c|}{$\begin{array}{l}\text { Katılımcıların Eğitim Durumu Değişkenine Göre } \\
\text { Ki-Kare }\left(X^{2}\right)\end{array}$} & \multicolumn{3}{|c|}{$\begin{array}{l}\text { Katılımcıların Gelir Düzeyi Değişkenine Göre } \\
\text { Ki-Kare }\left(X^{2}\right)\end{array}$} \\
\hline İlköğretim & 24 & 52.5 & 1500 TL'den az & 12 & 52.5 \\
\hline Ortaöğretim & 120 & 52.5 & $1501-2000 \mathrm{TL}$ & 12 & 52.5 \\
\hline Ön lisans & 54 & 52.5 & $2001-2500 \mathrm{TL}$ & 126 & 52.5 \\
\hline Lisans & 12 & 52.5 & 2501 TL üzeri & 60 & 52.5 \\
\hline Toplam & 210 & 210.0 & Toplam & 210 & 210.0 \\
\hline $\operatorname{Ki-Kare}\left(X^{2}\right)$ & \multicolumn{2}{|c|}{$133.543^{* *}$} & $\operatorname{Ki-Kare}\left(X^{2}\right)$ & \multicolumn{2}{|c|}{$166.457 * *$} \\
\hline
\end{tabular}

Çalışanların yöneticilerine duydukları güveni belirlemek için yapılan Likert ölçeğindeki sorulara verilen cevaplara ait ortalama, standart sapma ve ki kare analiz sonuçları Çizelge 2'de gösterilmektedir. Elde edilen sonuçlara göre "Yöneticimi yakından tanıyanlar, onun işine bağlı olduğunu ve en iyi performansı ortaya koymak için çalışacağını bilir" sorusuna 4,14 değeri ile en yüksek katılıyorum cevabı verilmiştir. Aslında bu çalışanların patronlarını tanıdıklarını göstermektedir. Bunu 4,11 değeri "Beni dinleyeceğini bildiğim için, işimdeki zorluklar hakkında yöneticimle rahatlıkla konuşabilirim" sorusu izlemiştir. Buna göre çalışanlar işverenlerini iyi tanımanın yanında kendilerini özgür hissetmektedirler. Çünkü bu soruya büyük oranda katılmış olmaları ve işverenin kendilerini dinleme yönünde kararlı olması bir güven ortamının oluşmasını sağlamış gözükmektedir. En düşük katılma oranı ise 2,80 değeri ile "Yöneticimle birlikte çalıştığımız süre boyunca birbirimize bağılık hissettiğimizi söyleyebilirim" sorusu olmuştur. Aslına bakılırsa çalışan işverenine ve işverende çalışana belli ölçüde değer vermektedir. Ancak bunun çok ilerlemesi ve ciddi yetin bozulması istenmemektedir. Çünkü ortak çalışma ortamının olması bağlılık duygusunun tam olarak gelişmesini sağlamamaktadır. Elde edilen sonuçlara göre genel olarak çalışanlar yöneticilerinden memnundurlar.

Verilen cevaplar arasındaki farklılığın önemli olup olmadığını belirlemek için yapılan ki kare analiz sonuçlarına göre bütün özellikler bakımından önemlilik görülmüştür ( $P>0,01)$. Bu sonuçlar aslında çalışanların işverenleri hakkında belli bir seviyede güven duymakla birlikte kafaların netleşmediği ve bir miktarda karışıklığın olduğu görülmektedir. Örneğin "Yöneticimle birlikte çalıştığımız süre boyunca birbirimize bağlılık hissettiğimizi söyleyebilirim" sorusuna \%45.7'lik bir kesimin katılmıyorum cevabını vermiş olması bunun örneğini oluşturmaktadır.

Yapılan çalışmada elde elden veriler arasındaki ilişkilerin belirlenmesi için yapılan spearman korelasyon sonuçlarına göre cinsiyet bakımından işverene güven düzeyleri arasında bir ilişki bulunmamıştır ( $r=0.147)$. Çalışan erkekte olsa bayanda olsa işveren hakkında benzer düşüncelere sahiptirler. Yaş olarak bakıldığında yaş ilerledikçe işveren güven duygusunun ve bilgi paylaşım miktarının önemli ölçüde arttığı belirlenmiştir ( $r=$ $0.512^{* *}$ ). Aslında bu beklenen bir sonuçtur. Çünkü 
yaş ile birlikte deneyimde arttığından doğru ile yanlışı ayırt etmek yeteneği de artmaktadır. Eğitim seviyesi artıkça işvereni anlama ve onunla daha rahat iletişim kurma sağlanmaktadır $\left(r=0,459^{*}\right)$. Eğitimin seviyesinin artması aynı zamanda çalışmadaki kararlılık açısından da önemlidir. Eğitim seviyesi işe çalışma sürelerinin arasındaki ilişkinin yüksek ve önemli olması $\left(r=0,428^{*}\right)$ da bunu teyit etmektedir. Bununla bağlantılı olarak toplam çalışma sürelerinin de artması benzer şekilde işverene olan bağlılığı artırmaktadır. Yıl geçtikçe işveren çalışanı, çalışanda işvereni tanıdığı için iletişim daha rahat bir şekilde yapılabilmektedir. Çalışma süresi arttıkça işyerine olan bağlılığın önemli derecede artması da buna bir göstergesi olarak değerlendirilmiştir $\left(r=0,538^{* *}\right)$. Eğer çalışanlar yeterli geliri elde ediyorlarsa çalıma düzenlerini bozmamaktadırlar. Çünkü gelir ile çalışma süreleri arasındaki ilişki önemli ancak negatif yönlü olmuştur $\left(r=-0,465^{* *}\right)$. Buna göre diğer bütün faktörler iyi olsa bile çalışanlar yeterince maaş alamıyorlarsa zorunlu olarak başka işlere bakmaktadırlar.

Çizelge 2. Çalışanların yöneticiye duydukları güven düzeyleri

\begin{tabular}{|c|c|c|c|c|c|c|c|c|c|}
\hline İfadeler & & : & 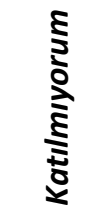 & 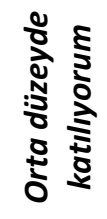 & 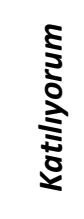 & 音 & $\begin{array}{r}\frac{8}{5} \\
\times \frac{0}{0} \\
\frac{0}{0}\end{array}$ & 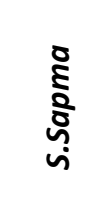 & $\begin{array}{c}\chi^{2} \\
\text { Ki-kare }\end{array}$ \\
\hline \multirow{2}{*}{$\begin{array}{l}\text { Yöneticimle düşüncelerimi. hislerimi ve } \\
\text { ümitlerimi özgürce paylaşabileceğim bir } \\
\text { ilişkim vardır }\end{array}$} & $f$ & 24 & - & 6 & 132 & 48 & \multirow[b]{2}{*}{3.85} & \multirow[b]{2}{*}{1.12} & \multirow[b]{2}{*}{$177.429 * *$} \\
\hline & $\%$ & 11.4 & - & 2.9 & 62.9 & 22.9 & & & \\
\hline \multirow{2}{*}{$\begin{array}{l}\text { Beni dinleyeceğini bildiğim için. işimdeki } \\
\text { zorluklar hakkında yöneticimle } \\
\text { rahatlıkla konuşabilirim }\end{array}$} & $f$ & 24 & - & 12 & 66 & 108 & \multirow[b]{2}{*}{4.11} & \multirow[b]{2}{*}{1.26} & \multirow[b]{2}{*}{$108.857^{* *}$} \\
\hline & $\%$ & 11.4 & - & 5.7 & 31.4 & 51.4 & & & \\
\hline \multirow{2}{*}{$\begin{array}{l}\text { Yöneticimin başka işletmeye geçmesi } \\
\text { durumunda onunla çalışamayacağım } \\
\text { için üzüntü duyarım }\end{array}$} & $f$ & 24 & 12 & 96 & 66 & 12 & \multirow[b]{2}{*}{3.14} & \multirow[b]{2}{*}{1.02} & \multirow[b]{2}{*}{$133.714^{* *}$} \\
\hline & $\%$ & 11.4 & 5.7 & 45.7 & 31.4 & 5.7 & & & \\
\hline \multirow{2}{*}{$\begin{array}{l}\text { Yöneticimle sorunlarımı paylaştığımda } \\
\text { ilgileneceğini ve yapıcı şekilde karşılık } \\
\text { vereceğini bilirim }\end{array}$} & $f$ & 24 & 12 & 72 & 78 & 24 & \multirow[b]{2}{*}{3.31} & \multirow[b]{2}{*}{1.11} & \multirow[b]{2}{*}{$89.143^{* *}$} \\
\hline & $\%$ & 11.4 & 5.7 & 34.3 & 37.1 & 11.4 & & & \\
\hline \multirow{2}{*}{$\begin{array}{l}\text { Yöneticimle birlikte çalıştığımız süre } \\
\text { boyunca birbirimize bağlıık } \\
\text { hissettiğimizi söyleyebilirim }\end{array}$} & $f$ & 12 & 84 & 60 & 42 & 12 & \multirow[b]{2}{*}{2.80} & \multirow[b]{2}{*}{1.01} & \multirow[b]{2}{*}{$92.571 * *$} \\
\hline & $\%$ & 5.7 & 40.0 & 28.6 & 20.0 & 5.7 & & & \\
\hline \multirow{2}{*}{$\begin{array}{l}\text { Yöneticim işine profesyonel olarak } \\
\text { yaklaşan ve kendini işine adayan } \\
\text { birisidir }\end{array}$} & $f$ & 24 & 72 & 6 & 72 & 36 & \multirow[b]{2}{*}{3.11} & \multirow[b]{2}{*}{1.35} & \multirow[b]{2}{*}{$82.286 * *$} \\
\hline & $\%$ & 11.4 & 34.3 & 2.9 & 34.3 & 17.1 & & & \\
\hline \multirow{2}{*}{$\begin{array}{l}\text { Yöneticimin geçmişine bakarak } \\
\text { yeteneğinden ve iş yapış şeklinden } \\
\text { şüphe duymak için bir neden } \\
\text { göremiyorum }\end{array}$} & $f$ & 12 & 24 & 66 & 96 & 12 & \multirow[b]{2}{*}{3.34} & \multirow[b]{2}{*}{0.95} & \multirow[b]{2}{*}{$133.714^{* *}$} \\
\hline & $\%$ & 5.7 & 11.4 & 31.4 & 45.7 & 5.7 & & & \\
\hline $\begin{array}{l}\text { Yöneticimin gereksiz işlerle işimi } \\
\text { zorlaştırmayacağını bilirim }\end{array}$ & $\begin{array}{l}f \\
\%\end{array}$ & $\begin{array}{c}24 \\
11.4\end{array}$ & $\begin{array}{c}48 \\
22.9\end{array}$ & $\begin{array}{c}30 \\
14.3\end{array}$ & $\begin{array}{c}84 \\
40.0 \\
\end{array}$ & $\begin{array}{c}24 \\
11.4\end{array}$ & 3.17 & 1.23 & $61.714 * *$ \\
\hline $\begin{array}{l}\text { Yöneticimi çok iyi tanımayan insanlar } \\
\text { bile ona güven ve saygı duymaktadır }\end{array}$ & $\begin{array}{l}f \\
\% \\
\end{array}$ & $\begin{array}{c}24 \\
11.4 \\
\end{array}$ & - & $\begin{array}{c}60 \\
28.6 \\
\end{array}$ & $\begin{array}{l}126 \\
60.0 \\
\end{array}$ & - & 3.37 & 0.96 & $76.457^{* *}$ \\
\hline $\begin{array}{l}\text { Yöneticimle daha önce çalışmış iş } \\
\text { arkadaşlarım onun güvenilir olduğunu } \\
\text { düşünmektedir }\end{array}$ & $f$ & 11.4 & 11.4 & 34.3 & 42.9 & $\begin{array}{c}24 \\
11.4\end{array}$ & 3.97 & 1.25 & $64.971 * *$ \\
\hline $\begin{array}{l}\text { Yöneticimi yakından tanıyanlar. onun } \\
\text { işine bağlı olduğunu ve en iyi } \\
\text { performansı ortaya koymak için } \\
\text { çalışacağını bilir }\end{array}$ & $f$ & 11.4 & - & - & 40.0 & 48.6 & 4.14 & 1.22 & $47.657^{* *}$ \\
\hline
\end{tabular}

\section{Sonuç ve Öneriler}

Araştırma sonucuna bakıldığında gıda sektöründe yer alan cips toptancılarındaki çalışanların \%97 sini erkek çalışanlar oluşturmaktadır. Çalışanların \%43'lük kısmı 20-29 yaş aralığında yer almaktadır. Bu durum dağıtım 
işinin bedensel güç ve kuvvete çok fazla bağlı olması ile açıklanabilir. Çalışanların \%57 gibi büyük çoğunluğu orta öğretim mezunlarından oluşmaktadır. Maaş düzeyleri incelendiğinde çalışanların genellikle asgari ücret seviyesinde maaş aldıkları görülmektedir. Maaş düzeyleri de eğitim düzeyleri ile paralellik göstermektedir. Çalışanların kıdemleri incelendiğinde \%40'lık kısmı 6-10 yıl arası çalışanlardan oluşmaktadır. Bu durum ise yöneticiye duyulan güvendeki kararsızlık sonucunda personel devir hızındaki artışa ve daha kısa süre işletmede ya da sektörde çalışmaya neden olmaktadır denilebilir. Çalışanların iş yerine bağlamasındaki en önemli faktörün aldığı maaş olduğu anlaşılmaktadır. Bunun için bu tür işyerlerinde çalışanların temel ihtiyaçlarının karşılanabileceği maaşın verilmesi faydalı olacaktır.

$\mathrm{Bu}$ çalışma sonunda çalışanların işverenleri hakkında belli bir seviyede güven duymakla birlikte kafalarında bir miktarda karışıklığın olduğu görülmektedir. Örneğin "Yöneticimle birlikte çalıştığımız süre boyunca birbirimize bağlılık hissettiğimizi söyleyebilirim" sorusuna yaklaşık $\% 46^{\prime}$ lık bir kesim katılmıyorum şeklinde cevap vermesi bu durumu açıklar niteliktedir.

Kişisel çıkarlarını düşünmediğini astlarına gösteren ve hissettiren yöneticilerin ve kişisel bütünlüğü ve yönetsel etkililiğini arttırmış yöneticilerin sayılarının artması neticesinde işgörenlerdeki yöneticiye duyulan güven artmakta bu durum da işgören devir hızının azalması, performansın ve verimliliğin artması gibi olumlu hususları beraberinde getirecektir. Dolayısı ile en temel işletme amacı olan karlılık da arttırılmış olacaktır.

\section{Kaynaklar}

Albayrak, M. 2009. Yaş Meyve ve Sebze Pazarlama Merkezler: Toptancı Haller-Pazarlar Dünya, Avrupa Birliği ve Türkiye'den Örneklerle Yapısı ve İşleyişi. Ankara, TEAE Yayınları, no:177.

Arslantaş, C.C. 2008. Yöneticiye duyulan güvenin ve psikolojik güçlendirmenin örgütsel vatandaşlık davranışı üzerindeki etkilerini belirlemeye yönelik görgül bir çalışma. TISK Academy/TISK Akademi, 3(5): 100-117.
Aslan, Ş., Özata, M. 2009. Lider-üye etkileşiminin (LMX) yöneticiye duyulan güven düzeyine etkisi. Sosyal Ekonomik Araştırmalar Dergisi, 9(17): 94-116.

Connell, J., Ferres, N., Travaglione, T. 2003. Engendering trust in manager-subordinate relationships: Predictors and outcomes. Personnel Review, 32(5): 569587.

Erbay, R. 2007. Lisanslı depoculuğun ve teslimata bağlı işlemlerin Türkiye tarım ürünleri piyasasına ve vadeli işlemlere olası etkileri. İstanbul. iTO yayınları.

Eren, S.S., Hayatoğlu, Ö. 2012. Etik iklimin satış elemanlarının iş tutumlarına ve iş performanslarına etkisi: İlaç sektöründe bir uygulama. Uluslararası Yönetim iktisat ve işletme Dergisi, 7(14), 109-128.

Eryılmaz, B. 2011. Kamu Yönetimi: Düşünceler, Yapılar, Fonksiyonlar, Politikalar. Ankara, Okutman Yayıncılık.

Karahan, Y. 2019. Türkiye'de patates sanayisinin gelişimi ve gelecekle ilgili beklentiler. https://www.turktob.org.tr/dergi/makaleler /dergi10/27-29.pdf (ET: 27.11.2019).

McAllister, Daniel J. 1995. Affect and CognitionBased Trust as Foundations for Interpersonal Cooperation in Organizations, Academy of Management Journal, 38(1): 24-59.

Mutlu, Ş. 2016. Piyasada Satışa Sunulan Cips ve Gevreklerde GDO Varlığının Araştırılması. Yüksek Lisans Tezi Namık Kemal Üniversitesi Fen Bilimleri Enstitüsü Gıda Mühendisliği Anabilim Dalı. Tekirdağ.

TÜRKTOB, 2018. Türkiye Tohumcular Birliği Kayıtları, Ankara (ET: 27.11.2019).

Yolaç, S. 2011. Yöneticinin algılanan liderlik tarzı ile yöneticiye duyulan güven arasındaki ilişkide lider üye etkileşiminin rolü. Öneri Dergisi, 9(36): 63-72.

Yurdakul, O., Koç, A. 1997. Gıda Ürünleri Pazarlaması, Çukurova Üniversitesi Genel Yayın No: 121. Ders Kitapları Yayın, (34): 257-258. 